\title{
補綴前処置としての臨床的歯冠長延長術および外科的挺出の併用
}

\author{
鎌田透申基䓀荒木久生宮田隆
}

\section{Combination Technique of Osseous Surgery for Crown-Length- ening Procedure and Surgical Extrusion Prior to Prosthodontics}

\author{
Tohru Kamata Kitetsu Shin Hisao Araki and Takashi Miyata
}

Subgingival caries, an existing faulty restoration, or a fractured tooth may not only affect the amount of coronal support but may also extend apically into connective tissue.

In these cases, surgical extension of the clinical crown by means of crown-lengthening procedure is imperative if apical overextension of the subsequent restoration is to be avoided. In other instances, for example an existing excessive subgingival caries or extensive radicular cyst, crown-lengthening procedure or surgical extrusion or a combination of these is indicated. This report we present a case, existence of subgingival caries and radicular cyst in the upper anterior portion.

It performed two surgical procedures, that a crown-lengthening procedure and a surgical extrusion for the crown-lengthening and the removal of radicular cyst prior to restoration. In consequently, this procedure can maintaining appropriate crown length, keeping biological width, and restore esthetically.

緒言

歯科医療の大きな目標の一つに，いかに天然歯 を保護し，かつ失われかけた歯を保存するかとい うことがある. 臨床上, 抜歯の適応 ${ }^{1)}$ と考えられる 1. 歯肉縁下に深く潜った残根, 2 . 歯内療法的 に解決できない根尖病変や歯根亳胞を有する歯, 3. 正規の位置にない前歯や小臼歯，4．歯周病 が高度に進行した歯などは，この歯を抜歯し，歯 内療法処置や病変部の播爬を行い, 再度抜歯窩に 再植することにより, 保存が可能なケースが多く 認められる。現在は，そのような症例に対して抜 歯を行い, インプラント補綴も考えられるが，生
体にとってインプラント体は異物となる2).そこ で再植 ${ }^{3}$ を考えた場合，生理的に近い手段で欠損 を修復することにより，天然歯とまったく同じ歯 牙支持組織を構築することが期待できる．今回歯 肉縁下う蝕と歯根襄胞を認めた上顥前歯に対し， 歯周外科好置と外科的挺出 ${ }^{4)}$ を併用し，う蝕の顕 在化と歯根襄胞の摇爬によって歯の保存を試み, 現在まで良好に経過している症例についてここに 報告する。

\section{症例}
患 者：男性, 23 歳.
初 診: 平成 5 年 1 月 8 日。
主 訴: 12 部歯肉からの排膿。 
表 1 歯周組織診査 $(2+2)$

\begin{tabular}{|c|c|c|c|c|c|}
\hline \multicolumn{2}{|l|}{ Tooth } & $2\rfloor$ & 1 & \lfloor & 2 \\
\hline \multirow{2}{*}{$\begin{array}{r}\text { Probing depth } \\
(\mathrm{mm})\end{array}$} & $\mathrm{B}$ & $\begin{array}{l:ll}2 & 2 & 3\end{array}$ & $\begin{array}{l:l:l}3 & 2 & 4 \\
\end{array}$ & $\begin{array}{l:ll}2 & 2 & 2\end{array}$ & $\begin{array}{l:ll}2 & 2 & 2\end{array}$ \\
\hline & $\mathrm{P}$ & $\begin{array}{l:lll}2 & 1 & 2\end{array}$ & $\begin{array}{l:l:l}2 & 2 & 2 \\
\end{array}$ & $\begin{array}{l:l:l}1 & 2 & 2 \\
\end{array}$ & $\begin{array}{l:l:l}2 & 2 & 2\end{array}$ \\
\hline \multicolumn{2}{|c|}{ Mobility (Miller) } & $\mathrm{M}_{0}$ & $\mathrm{M}_{0}$ & $\mathrm{M}_{0}$ & $\mathrm{M}_{0}$ \\
\hline \multicolumn{2}{|l|}{$\mathrm{BOP}(+,-)$} & - & - & - & - \\
\hline
\end{tabular}

BOP : Bleeding on probing

\section{既往歴 :}

全 身；特記事項なし。

歯 科；2 1|1 2 は, 2 年前歯内療法処置後, 歯冠修復が行われていたが, 6 力月前から 12 唇, 口蓋側根尖部歯肉が腫脹し，排膿を繰り返してい た。

現 症：(

口腔内所見；1|12 に辺縁不適合なレジン前装 冠が装着されており，歯頸線の高さやその形態の 不調和が認められた（図 1 ).

X線所見：不完全な根管充填が行われており， $\lfloor 12$ の根尖部に鳩卵大の透過像，2」の根尖部には 小豆大のやや不明瞭な透過像が認められる（図 2 ).

歯周組織所見：プロービングデプスは，平均 $2.1 \mathrm{~mm}$ でプロービング時の出血や病的な動摇は 認められない（表 1 )。

\section{処置および経過}

本症例では， 12 の抜歯と歯根襄胞の摘出も考 えられたが，患者が比較的若年者であり，また， 抜歯したくないという患者の希望を考慮し，でき る限り保存的療法のみで治療を行い, 治療効果の 上がらなかった場合には，抜歯するという方針で 患者の同意を得た。そこで，治療上あらかじめ検 討すべき点を考慮し治療計画を立案した。まず, 2 1|1 12 は, 通法に従って歯内療法処置を行い, その後，歯周外科を行う事にした。ここでの歯周 外科の目的としては, 歯周ポケットの除去はもち ろん, 骨切除によるう蝕の顕在化, および歯頸線 の位置との調和のとれたスキャロープ形態を獲得
表 2 治療計画 $(2+2)$

歯周初期治療

TBl, Scaling, Root planing

2 1|12 : 不適冠除去, テンポラリークラウン装着

211122 : 感染根管処置

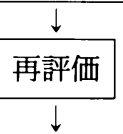

歯周外科処置

$21 \mid 12$ : 臨床的歯冠長延長術

$1 \mid 2$ : 歯の再植による外科的挺出 (歯根襄胞の搔爬)

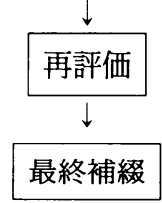

することである．また，歯槽骨の切除だけではう 蝕の顕在化ができない恐れのある 112 に対して は, 一度抜歯し，歯を挺出させた状態で再植する 外科的挺出を行い, この時同時に抜歯窩から歯根 襄胞の搔爬を行うこととした(表 2 )。まず，上䪽 4 前歯のポストを除去し，歯内療法処置を行った 後，1112 には歯肉縁下う蝕が認められたため, 可及的に軟化象牙質を除去し, 術後の歯間乳頭の 喪失を生じないよう正中部のみパピラプリザベー ションテクニックラ゙用いた切開を入れ，歯周外 科を行った(図 $3 \sim 6$ ). この時, 歯槽骨の切除は, 骨縁上に健全歯質を $4 \mathrm{~mm}$ 露出させ，生物学的幅 径6)確保するよう試みたが，1|12 は，かなりの 骨削除量が必要となるため骨切除のみによる臨床 的歯冠長の延長を断念し， $1\lfloor 2$ の外科的挺出を 行った. $1 \mid 2$ の抜歯の際，歯根になるべく損傷を 与えないように注意して抜歯を行い，その抜歯窩 から歯根襄胞を搔爬した（図 7，8)。その間抜去 歯は, 乾燥と污染を防止するために, 生理食塩水 に浸しておいた，抜歯窩に歯を再植するときは， 歯の健全歯質を骨緑上に出すため, 約 $8 \mathrm{~mm}$ 挺出 させた状態で再植をした(図 9 ). テンポラリーク ラウンは，外科的挺出を行わなかった支台歯のみ で固定し，歯周包帯を行った。再植した $1 \mid 2$ は, 術後, 2 力月頃から動摇が消退し始めたためプロ 


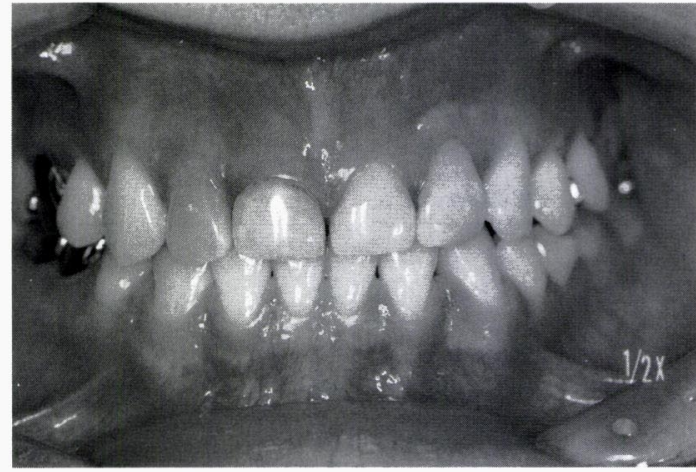

図 1 初診時口腔内正面観

1112 2 のレジン前装冠は, 適合, 形態とも不良 12 は, 根尖相当歯肉が腫脹し排膿を繰り返し ている

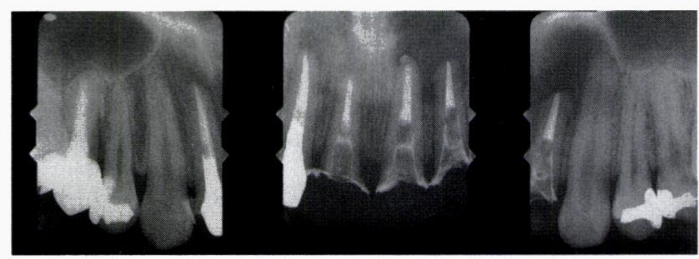

図 $32+2$ 歯内療法処置後のデンタルX線写真 2|は歯肉縁上に十分な健全歯質が存在していた 為，メタルコアーによる支台築造を行ってある

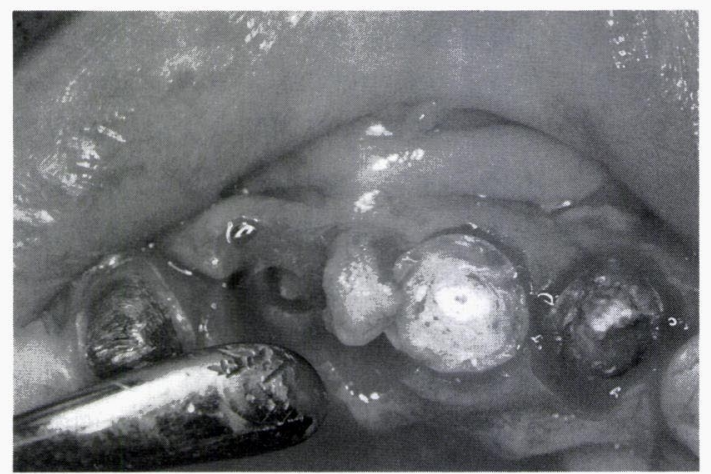

図 $52+2$ に歯周外科 (クラウン・レンスニ ング）を行う審美的配慮として正中部の みパピラプリザベーションテクニックを 用いる

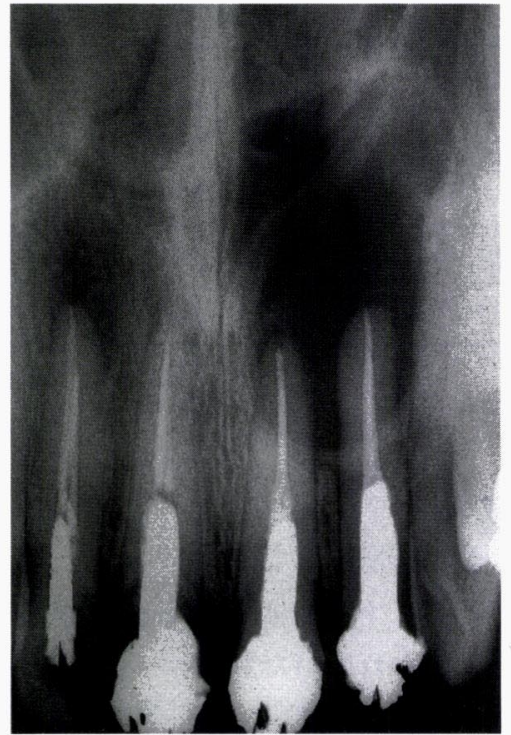

図 2 初診時デンタルX線

不適切と思われる歯内療法処置と $2 \mid 12$ 根尖部 はX線透過像を認める

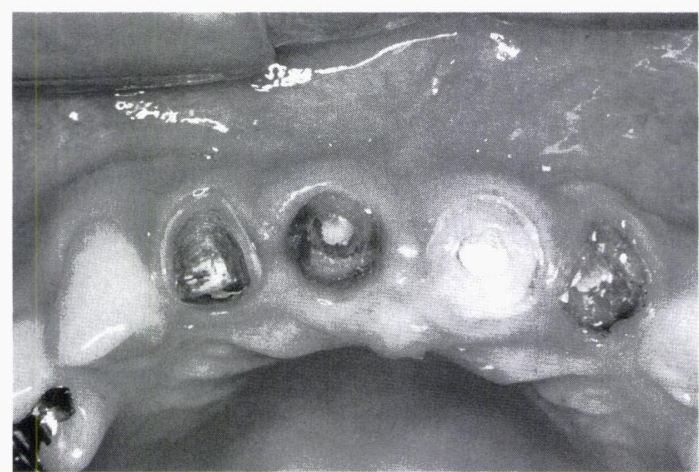

図 4 歯周外科直前の状態

$1 \mid 2$ には，歯肉縁下深くまでう蝕が及んでいる 骨切除のみでは健全歯質を確保できない部分に は，外科的挺出も考えておく

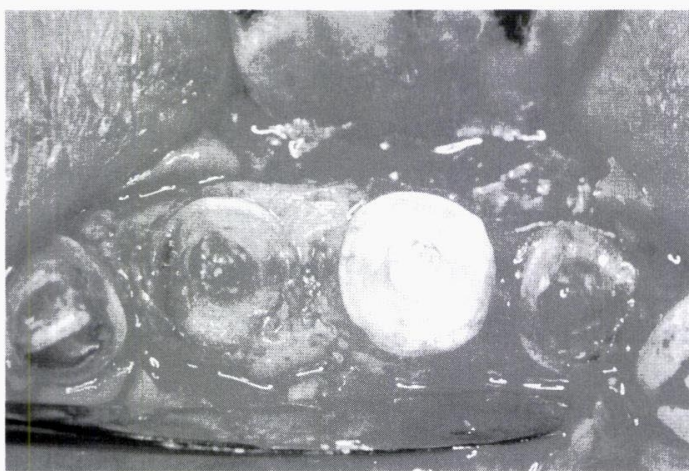

図 $61 \mid 2$ は骨切除のみでは十分な歯質が確保 できなかったため外科的挺出に踏み切る 


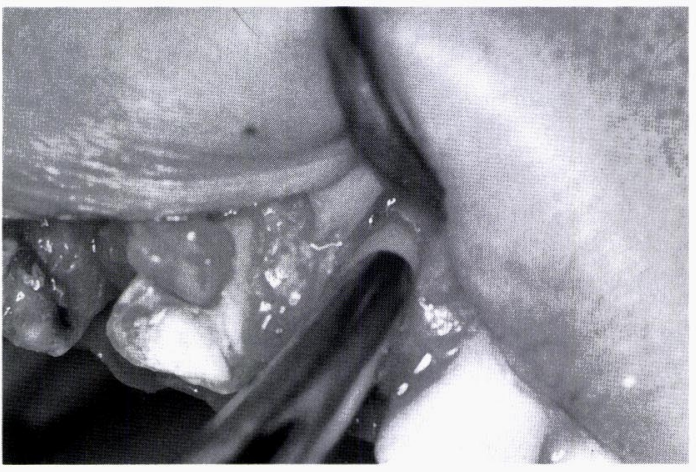

図 $7\lfloor 2$ の抜歯

根面の歯根膜にできる限り損傷を与えないよう に注意する，1山抜歯後, 抜歯窩内に保存して ある状態

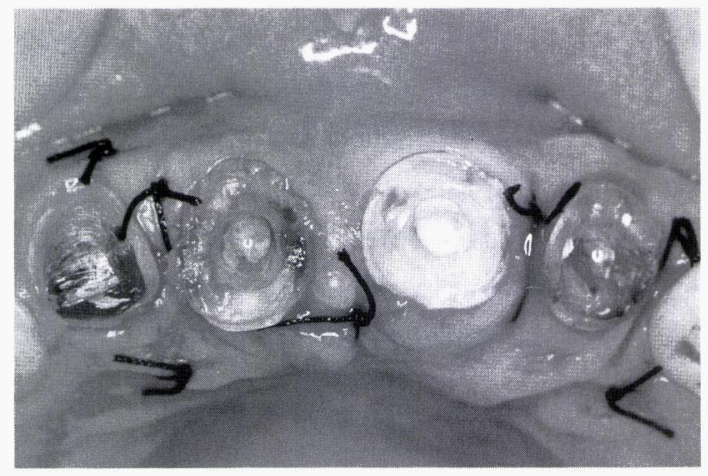

図 $9 \underline{1 \mid 2}$ を約 $8 \mathrm{~mm}$ 元の位置から挺出させた 状態で再植しフラップを縫合

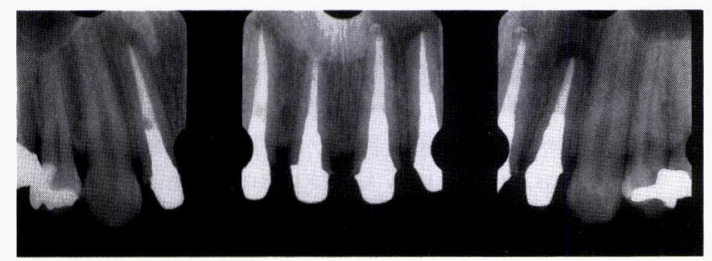

図 11 歯周外科後, 10 カ月のデンタルX線写真 根尖部の透過像は縮小してきており，歯根膜腔 や歯槽硬線の出現を認める

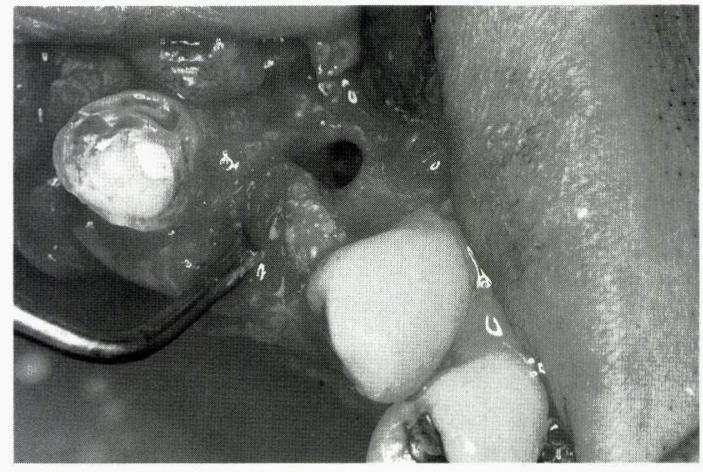

図 8 L抜歯窩内より多量の歯根囊胞内容物を搔爬

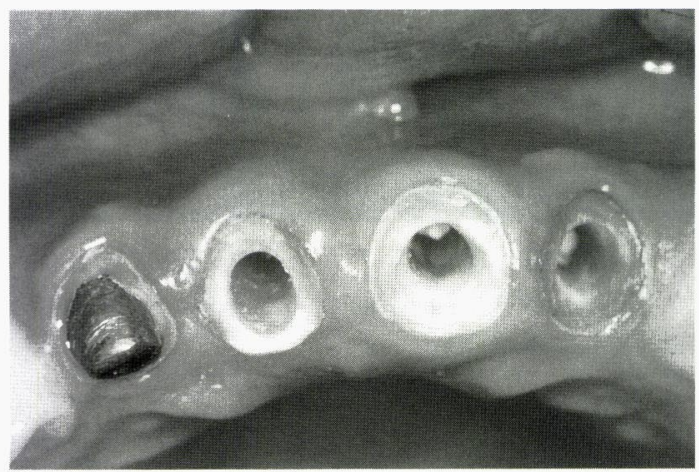

図 103 カ月のコアホール形成後の状態

この時点では, 再移植の動摇もおさまっている

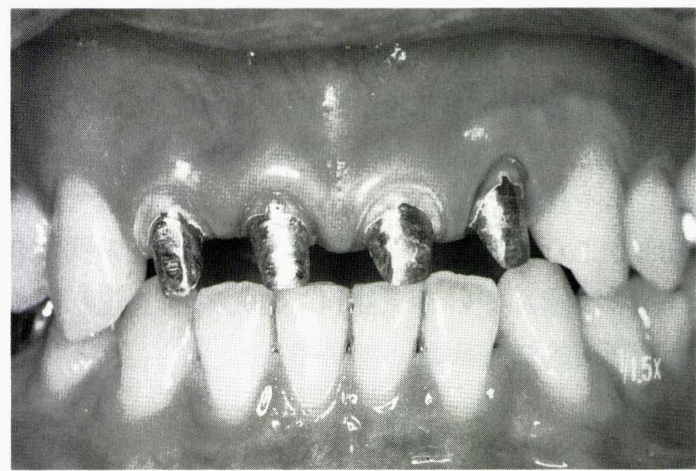

図 12 術後 10 力月の状態

歯頸線の位置やスキャロップ形態の改善が認め られる 


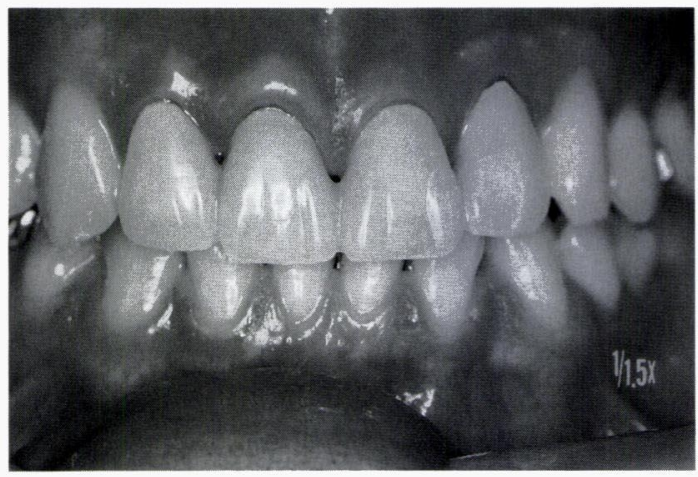

図 13 テンポラリークラウンを修正しながら 予後を判断し最終補綴へと移行していく

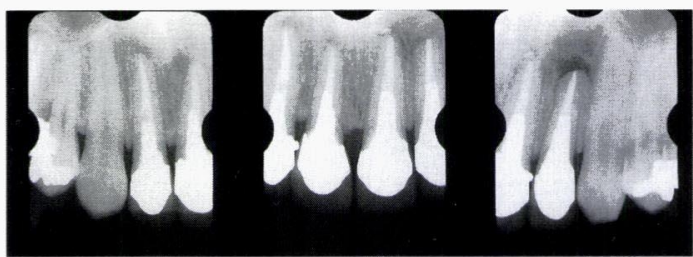

図 15 術後 2 年のデンタルX $\mathrm{X}$ 線写真 透過像はさらに縮小傾向にあり骨りょう構造が 回復してきている

ビジョナルレストレーションの支台歯として活用 し, 術後 3 力月後に異常な動摇がなくなったため, 軟化象牙質を除去しコアホールを形成した（図 10). 術後 10 カ月のデンタルX線写真では, 透過 像は縮少傾向を示し，歯根膜腔も明瞭になりつつ あり, 骨梁構造も出現してきている. 最終的にテ ンポラリークラウンの形態修整を行い, 歯頸線の 位置や形態は改善され，周囲と調和している（図 11〜13). 術後 15 力月で最終補綴物に移行し, 現 在 2 年を経過している。デンタルX線写真では透 過像もさらに縮小し骨梁構造や歯根膜腔の明瞭化 がさらに進んでいる（図 14, 15). 患者は違和感も なく審美的にも満足している.

\section{考察・まとめ}

本症例では, 再植挙上歯の適応 ${ }^{7)}$ あるように 付着が $1 / 2$ 以上で，単根歯であり，歯根長が 13

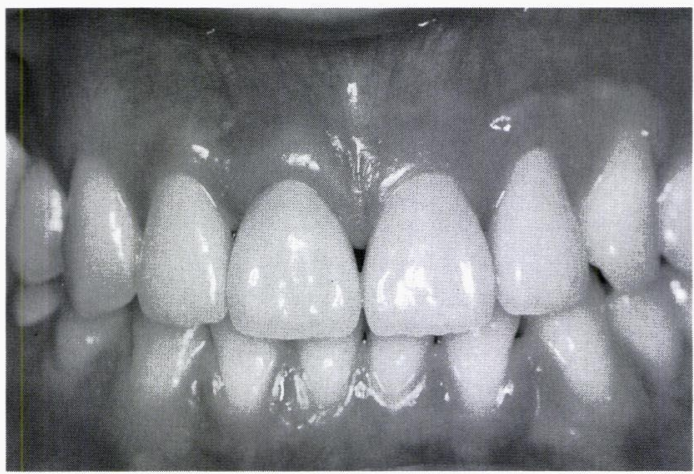

図 14 術後 15 カ月でセラモメタルクラウンを 単冠で装着

術後の経過は良好で, 審美的な改善もできてい る

$\mathrm{mm}$ 以上あるなどの条件を満たしていたため, 外 科的挺出を行うことができた．意図的再植する場 合, 再植する時間が短く歯根膜をなるべく損傷さ せないようにし, 感染部位は搔爬することにより， 良好な予後が期待できる. 歯肉縁下カリエスや歯 根囊胞があり, 最終補綴物の審美性やメインテナ ンスの面で歯周外科や歯内療法のみでは対応しき れない場合に, 意図的再植は有効な手段と思われ る.

\section{参考文献}

1) 宮崎 正：口腔外科学. 第 1 版：397〜 426, 医 歯薬出版 (東京), 1989.

2）下野正基，飯島国好：治癒の病理。第 1 版：1 ～10, 医歯薬出版 (東京), 1995.

3）下野正基，飯島国好：治癒の病理。第 1 版： 54 80, 医歯薬出版 (東京), 1995.

4) Andreasen, J. O. and Andreasen, F. M.（松本 光吉ほか訳) : カラーアトラス外傷歯の治 療.：54 80, 医歯薬出版 (東京), 1992.

5) Carranza, F. A. Jr. : Glickman's Clinical Periodomtology. 7th ed. : 792 810, W. B. Saunders (Philadelphia), 1990.

6）佐藤直志：歯周補綴の臨床と手技.：170～184, クインテッセンス出版 (東京), 1992.

7）月星光博：移植の適応症の拡大, ザ・クインテッ センス, 14(12)：90〜94, 1995.

別刷請求先：申 基喆

明海大学歯学部歯科臨床研究所 